НАУКОВИЙ ВІСНИК

Sientific messenger of Lviv National University

(2)

VIIIII

серія "Слльсько

Tom $22 \times 93$

2020
Науковий вісник Дьвівського національного університету ветеринарної медицини та біотехнологій імені С.3. Гжицького. Серія: Сільськогосподарські науки

Scientific Messenger of Lviv National University of Veterinary Medicine and Biotechnologies. Series: Agricultural sciences https://nvlvet.com.ua/index.php/agriculture

UDC 34.349 .6

\title{
Assessment of the potential and use of recreational resources of Stryj district of Lviv region
}

\author{
B. M. Kalyn, M. V. Stanishevska
}

Stepan Gzhytskyi National University of Veterinary Medicine and Biotechnologies Lviv, Ukraine

Article info

Received 01.09.2020

Received in revised form 01.10 .2020

Accepted 02.10.2020

Stepan Gzhytskyi National University of Veterinary Medicine and Biotechnologies Lviv,

Pekarska Str., 50, Lviv. 79010, Ukraine.

Tel.: +38-096-289-52-40

E-mail:dana24b@ukr.net
Kalyn, B. M., \& Stanishevska, M. V. (2020). Assessment of the potential and use of recreational resources of Stryj district of Lviv region. Scientific Messenger of Lviv National University of Veterinary Medicine and Biotechnologies. Series: Agricultural sciences, 22(93), 97-101. doi: $10.32718 /$ nvlvet-a9317

In Lviv region, the development of the recreational sphere is a strategic landmark. Natural recreational resources of Lviv region and the largest in Ukraine in number, diversity and degree of preservation of historical and cultural resources have led to significant development of the industry. However, the territory of the region is characterized by varying degrees of development of recreational resources and development of recreational potential. The level and intensity of the current use of the potential of recreational resources of Stryi district are estimated. Due to the favorable geographical location, favorable climatic resources, a significant number and diversity of historical and cultural recreational resources, Stryi district has significant potential for the development of recreation. One of the main components of therapeutic recreation is the availability of natural therapeutic recreational resources - mineral waters and therapeutic mud-in the area. Morshyn has the largest number of mineral water sources, which are characterized by high sulfate content. 21 objects of the nature reserve fund have been created on the territory of the district, which has a high value for the organization of recreational activities and allows to consider them as the most important component of natural recreational resources. The potential of recreational resources of Stryi district is determined, which is 0.46 and corresponds to the average attractive level. Separate recreation centers have been formed within the district. This is, first of all, the city of Stryi, which has a significant number of historical and cultural resources, the city of Morshyn - as a center of medical and recreational recreation. The proximity to these cities of protected areas increases their recreational potential. Threats to further recreational use of nature are a significant anthropogenic load on the environment, irrational use of natural recreational resources and low investment activity in the development of the industry. Priorities for the development of recreational activities are the identification and use of new types of recreation, unique features of individual territories, popularization of their historical and ethnographic features, increasing the share of objects of will, in particular national importance.

Key words: Stryi district, natural resources, historical and cultural resources, territories of the will, recreational activity.

\section{Оцінка потенціалу та використання рекреаційних ресурсів Стрийського району Львівської області}

\author{
Б. М. Калин, М. В. Станішевська
}

Львівський національний університет ветеринарної медицини та біотехнологій імені С. 3. Гюицького, м. Львів, Україна

Для Львівської області розвиток рекреаційної сфери є стратегічним орієнтиром. Природні рекреаційні ресурси Львівщини та найбільші в Україні за кількістю, різноманітністю і ступенем збереження історико-культурні ресурси спричинили значний розвиток галузі. Проте територія області характеризується різним ступенем освоєння рекреачійних ресурсів та розвитку рекреаційного потенціалу. Оцінено рівень та інтенсивність поточного використання потенціалу рекреаційних ресурсів Стрийського райо- 
ну. Завдяки вигідному географічному розташуванню, сприятливим кліматичним ресурсам значній кількості та різноманітності історико-культурних рекреаційних ресурсів Стрийський район має значний потенціал для розвитку рекреації. Одними з головних складових лікувальної рекреації є наявність природних лікувальних рекреаційних ресурсів - мінеральних вод та лікувальних грязей на території району. У м. Мориин зосереджена найбільша кількість джерел мінеральних вод, які характеризуються підвищеним вмістом сульфатів. На території району створено 21 об'єкт природо-заповідного фонду, цио має високу ияінність для організації рекреачійної діяльності та дозволяє розглядати їх як найважливішу складову природних рекреаційних ресурсів. Визначено потенціал рекреаційних ресурсів Стрийського району, який становить 0,46 та відповідає середньоатрактивному рівню. В межах району сформувались окремі центри рекреації. Це, насамперед, м. Стрий, щуо має значну кількість історико-культурних ресурсів, м. Моршин - як ичентр лікувально-курортної рекреаціі. Близькість до ичх міст заповідних об'єктів підвищує їх рекреаційний потенціал. Загрозами подальшого рекреаційного природокористування є значне антропогенне навантаження на навколишнє природне середовище, нераціональне використання природних рекреаційних ресурсів та низька інвестиційна активність в розвиток галузі. Пріоритетними для розвитку рекреаційної діяльності є виявлення та використання нових видів рекреації, унікальних особливостей окремих територій, популяризачія їх історико-етнографічних особливостей, збільшення частки об'єктів заповідання, зокрема загальнодержавного значення.

Ключові слова: Стрийський район, природні ресурси, історико-культурні ресурси, території заповідання, рекреаційна діяльHicmb.

\section{Вступ}

До рекреаційної ресурсів належить будь-яка діяльність, спрямована на відновлення сил людини; пов'язана з використанням вільного часу людей для їх оздоровчої, культурно-ознайомчої і спортивної діяльності на спеціалізованих територіях, що може здійснюватися як на території постійного проживання людини, так і за іï межами які знаходяться поза їх постійним помешканням (Tretiak \& Hrebennyk, 2014). Основою формування рекреації є використання наявних рекреаційних ресурсів та можливість їх поєднання для створення атрактивного середовища життя населення. Цей вид діяльності має чітко виражену природно-ресурсну орієнтацію.

Львівщина належить до регіонів, де перспективи розвитку рекреаційної галузі є найвищими в державі. Рекреаційна галузь області набула значного розвитку завдяки вигідному географічному положенню, багатому природно-ресурсному та історико-культурному потенціалу. У загальноукраїнському природноресурсному потенціалі частка природного рекреаційного потенціалу Львівщини складає 5,38 \% (Horyn, 2018). На території області налічується понад 4000 історико-культурних пам'яток. Проте не всі території області характеризуються рівномірним розподілом рекреаційних ресурсів та ступенем їх освоєння (Kalyn \& Butsiak, 2017).

Meта статmi - вивчення наявного стану та використання природних й історико-культурних рекреаційних ресурсів та їх потенціалу, визначення загроз та напрямів раціонального їх використання.

\section{Результати та їх обговорення}

Територія Стрийського району має досить високий потенціал для рекреаційної діяльності природних рекреаційних ресурсів. Кліматичні ресурси є складовою природно-ресурсного потенціалу та визначають рекреаційну привабливість регіону, його територіальну і змістовну організацію.Клімат Стрийщини помірно-континентальний, 3 незначною кількістю сонячних днів та середньорічною температурою повітря 7,2 ${ }^{\circ} \mathrm{C}$. Річний радіаційний баланс земної поверхні достатній - 49 ккал/см². Кількість опадів становить 750-800 мм, протягом року переважають західні і північно-західні вітри.

Значним рекреаційним потенціалом володіють лісові насадження. У структурі земель вони займають 24,8 \% загальної площі району (рис. 1) і це є досить високим показником в області порівняно 3 іншими районами.

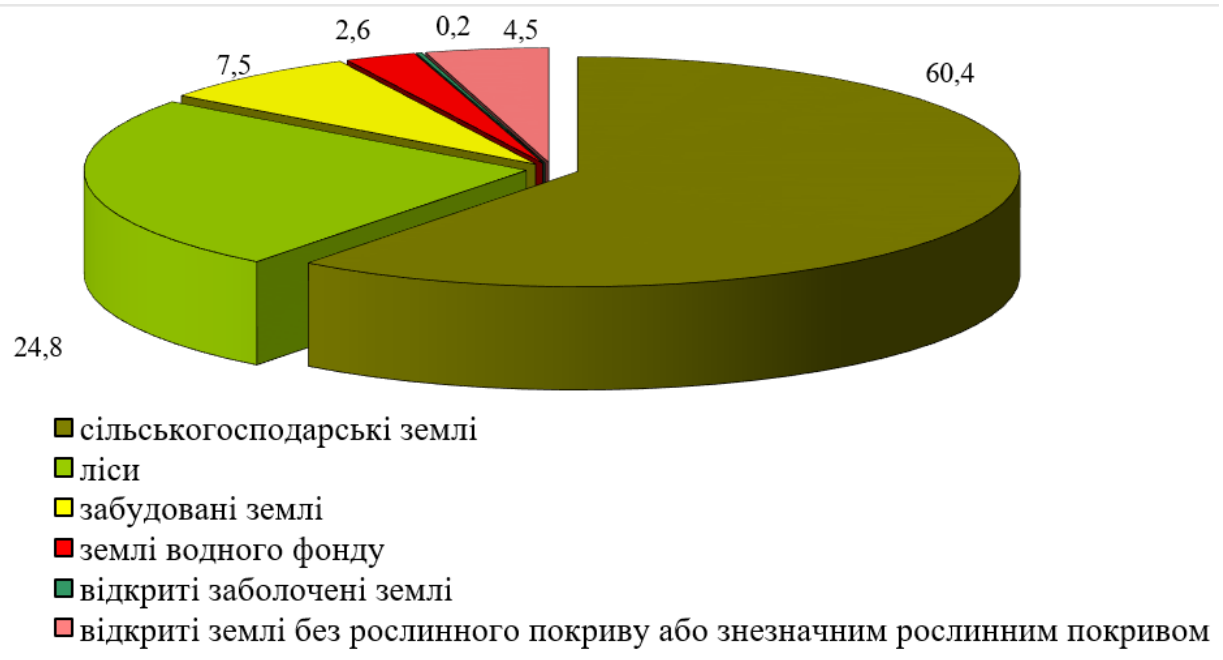

Рис. 1. Структура земельного фонду Стрийського району, \% 
Для використання лісових насаджень з рекреаційною метою має значення видовий склад та вік деревостанів. Основними лісоутворюючими породами на території району є дуб, бук, вільха, а найбільшу площу займають середньовікові насадження, які вважаються найсприятливішими для рекреації (Chabanchuk \& Melniichuk, 2015).

Багатий район і на гідрологічні ресурси. У межах району виділяють басейни річок Стрий, Колодниця, Свіча та Бережниця; усі вони належать до басейну Дністра. Загальна довжина річок становить 283 км. Мережа цих річок $є$ придатна для активних видів відпочинку та оздоровлення.

Головна річка району Стрий бере початок в Українських Карпатах та впадає у Дністер за 10 км на схід від Жидачева. Довжина річки 232 км, площа басейну 3,06 тис. км² (Vyshnevskyi \& Kosovets, 2003).

Крім природних водотоків у районі нараховується 181 ставок загальною площею водного дзеркала 552,54 га (Perkhach \& Hamoniak, 2016), які теж активно використовуються для рекреації.

Видове різноманіття ландшафтів напряму пов'язане 3 рекреаційною діяльністю. За фізикогеографічним районуванням Стрийський район розташований в межах фізико-географічної області Дністровського Передкарпаття та двох фізикогеографічних районів - Стрийського передгір'я та Присвіцького горбогір'я. Відповідно у ландшафтній структурі переважають передгірні акумулятивноденудаційні плоскі височини і річкові долини 3 дерново-підзолистими поверхнево-оглеєними, дерновими і лучними грунтами під широко-листяними (буководубовими) і хвойними лісами (Nazaruk, 2018).

Одним 3 найважливіших складових лікувальної рекреації $є$ наявність природних лікувальних рекреаційних ресурсів. Важливим центром лікувальнокурортної рекреації $є$ м. Моршин, де зосереджена найбільша кількість джерел мінеральних вод, що характеризуються підвищеним вмістом сульфатів. Сумарні розвідані та прогнозовані ресурси лікувальних розсолів становлять понад $600 \mathrm{~m}^{3}$ /добу (Mahas, 2003). Досить значні в районі запаси лікувальних грязей. Лікувальні торф'яні грязі Стрийщини представлені Моршинським родовищем. Воно $є$ найбільшим серед родовищ в Україні, запаси грязей становлять 239 тис. м $^{3}$ (Chyr \& Hrab, 2015).

Основне завдання заповідних території полягає у збереженні типових для певної місцевості об'єктів, охорона та відновлення цінних рідкісних природних комплексів. Проте саме природоохоронні зони мають важливе рекреаційне та туристичне значення завдяки своїй унікальності, високій естетичній і пізнавальній цінності (Pankiv, 2019).

Природно-заповідний фонд Стрийського району представлений 21 об'єктом що у відсотковому відношенні складає близько 4,23 \% площі району. У Львівській області цей показник є значно вищим і становить $7,84 \%$.

Як в області, так і в районі більшість заповідних об'єктів розташована на землях лісового фонду. Серед них ландшафтний заказник “Моршинський”, заповідні урочища “Розгірче”, “Березовий гай”, “Семи- гинів”. На жаль, усі вони мають статус природоохоронних об'єктів місцевого значення, що знижує їх можливості виконувати екологічні, соціальні та інформаційні функції. Єдиний об'єкт заповідання району має загальнодержавний статус. Це парк-пам'ятка садово-паркового мистецтва "Підгірцівський парк" площею 8,3 га, що розташований у с. Підгірці. У парку зростає багато цінних видів дерев і кущів, зокрема платани, граби.

Варто наголосити, що геопросторовий розподіл природно-антропогенних рекреаційних ресурсів $\epsilon$ нерівномірним. 9 об'єктів заповідання, серед яких 6 пам'яток природи та 3 - парки-пам'ятки садовопаркового мистецтва розташовані в м. Стрий. Сумарна їх площа становить лише 27,3 га, з яких 20 га - це площа Парку ім. Т. Шевченка. Решта об'єктів природно-заповідного фонду мають нерівномірне розташування. Вони в основному сконцентровані в східному, південному та південно-західному напрямах від м. Стрий. Найбільший за площею об'єкт - ландшафтний заказник “Моршинський” розташований на півдні (рис. 2).

Іншу групу ресурсів, що формують потенціал регіону, складають історико-культурні рекреаційні ресурси, які на Стрийщині представлені широким хронологічним періодом від XVIII до середини XX століття. Головні історико-архітектурні сакральні пам'ятки району розташовані у містах Стрию та Моршині, а також Семигинові, Підгірцях, Верчанах, Великих Дідушичах, Дулібах, Добрівлянах, Добрянах та інших населених пунктах. Загалом в районі нараховується 32 церковні споруди - пам'ятки архітектури місцевого значення та 7 культових споруд - пам'яток архітектури національного значення.

Серед пам'яток археології відомі городища у с. Кавське, Голобутів, могильники кургани в смт. Дашава, с. Йосиповичі, Комарів, Олексичі, Семигинів, кургани в с. Великі Дідушиці, Довголука, поселення в с. Загірне, с. Нижня Стинава, с. Олексичі, Маліцька культура в с. Ходовичі. Відоме за межами області є городище та наскельний печерний монастир с. Розгірче.

Історико-культурні ресурси району, що складаються з великої кількості пам'яток архітектури, істоpiї, сакральних споруд та пам'яток $є$ основою для розвитку екскурсійної діяльності та культурнопізнавальної рекреаціï (Prohrama rozvytku turyzmu..., 2007). Визначні місця та споруди входять у програми туристичних маршрутів, найбільш відвідуваними серед яких є: “З когорти нескорених", “Україною ми жили, за Україну полягли”, “Ландшафтна спадщина Стрийщини”, “Духовні прощі Стрийщини”, “7 чудес Стрийщини національного значення” та інші.

Визначено потенціал рекреаційних ресурсів Стрийського району, який становить 0,46 та відповідає середньоатрактивному рівню. До складу унікальних ресурсів Стрийського району належать як історико-культурні рекреаційні ресурси: музеї та музейні експозиції, так і природні - штучні водні об'єкти, бальнеологічні ресурси, що мають найвищий коефіцієнт. При цьому слід зазначити, що в межах району сформувались окремі центри рекреації. Це, насамперед, м. Стрий, що має значну кількість історико- 
культурних ресурсів, м. Моршин - як центр лікувально-курортної рекреації. Близькість до цих міст заповідних об'єктів підвищує їх рекреаційний потенціал.

Здійснення рекреаційної діяльності залежить від стану навколишнього природного середовища, не лише кількісної, а й якісної оцінки його компонентів. Стрийський район має досить розвинуту промисловість та високу щільність населення $(75,4$ ос./км²), що позначається значним антропогенним впливом на довкілля.
Динаміка викидів в атмосферне повітря від стаціонарних джерел забруднення Стрийського району (разом із містами Стрий і Моршин) представлена на рис. 3. Найменша кількість викидів спостерігалась у 2017 році, проте у 2018 році їх кількість зросла у 2,2 рази. У відсотках до показників області найнижче співвідношення становило 2,7 \% у 2017 році, а найвище $-5,7 \%$ у 2018 році. У територіальному розрізі за 2019 р. найбільше у розрахунку на квадратний кілометр викинуто забруднюючих речовин у місті Стрий - 36,2 т/км².

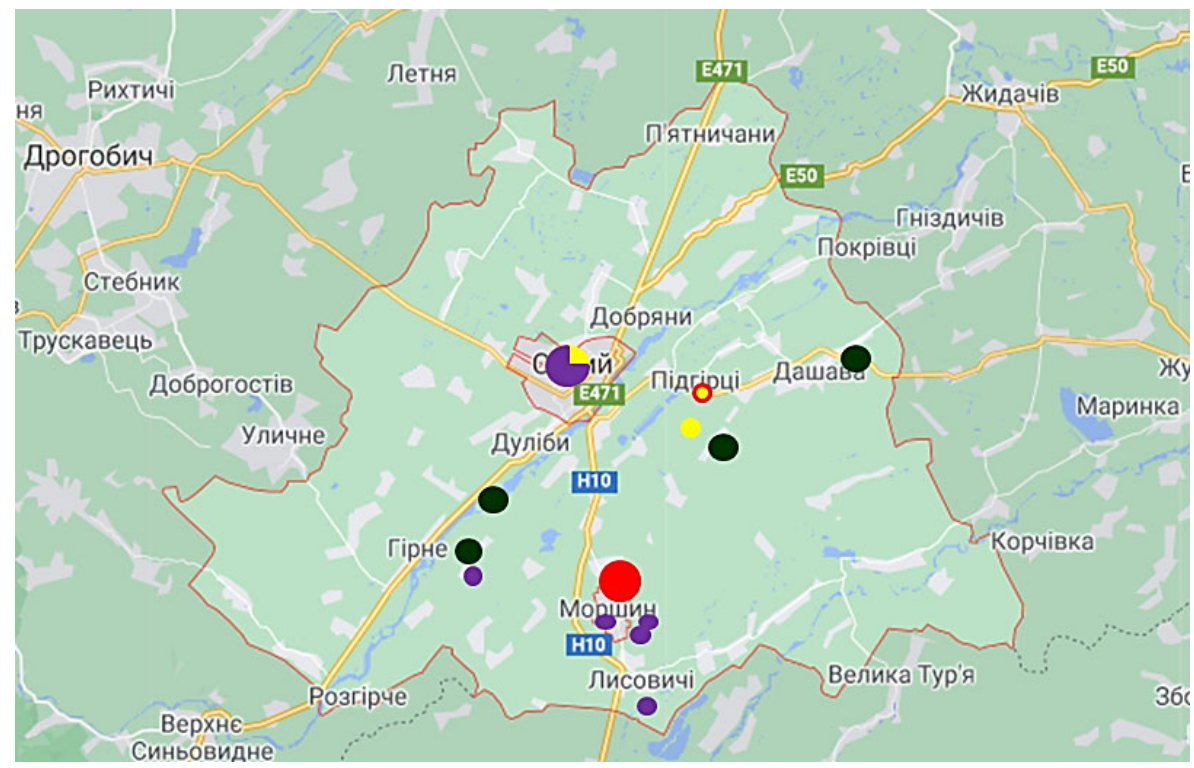

ландшафтний заказник;

заповідне урочище;

пам'ятка природи;

парк-пам'ятка садово-паркового мистецтва;

парк-пам'ятка садово-паркового мистецтва загальнодержавного значення.

Рис. 2. Розташування об'єктів ПЗФ у межах Стрийського району

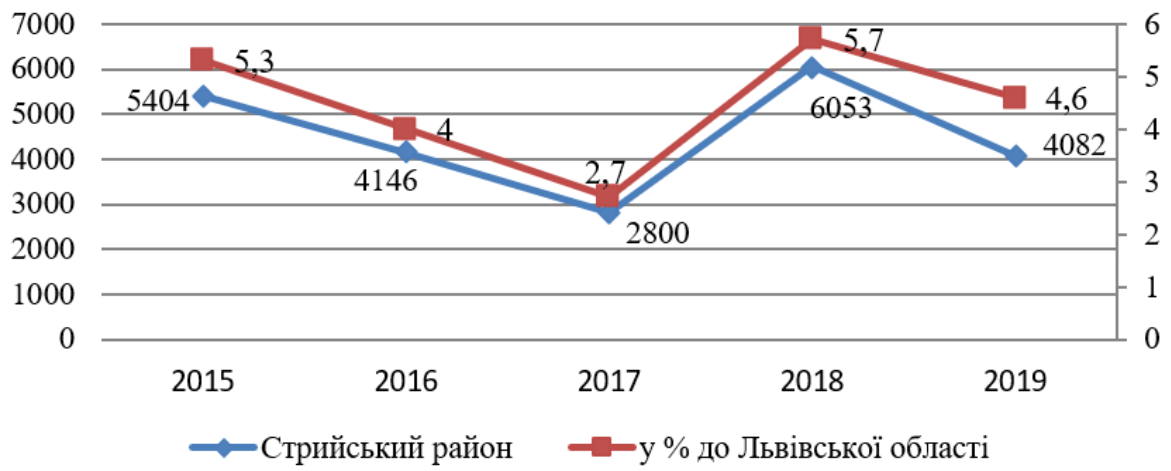

Рис. 3. Викиди забруднюючих речовин у атмосферне повітря від стаціонарних джерел забруднення, т

Проблемою є також скид зворотних вод у поверхневі водні об'єкти. Усі води м. Стрий та м. Моршин скидаються забрудненими, по району за період 20152019 pp. 30-50 \% зворотних вод були нормативно очищеними. Загальна проектна потужність очисних споруд складає 32 тис. $\mathrm{m}^{3} /$ добу, проте фактичний об'єм скиду є значно менший - близько 20 тис. $\mathrm{m}^{3} /$ добу. Більшістю очисних споруд здійснюється скид недостатньо очищених зворотних вод по зважених речовинах, БСК, ХСК, азоту амонійному, нітритах та інших забруднювачах.

Стрийщина характеризується низькою родючістю грунтів. Близько 60 \% грунтів - середньо- та сильнокислі. Середньозважений вміст гумусу менше 1,7\%. Значну частину земель району займають об'єкти нафто-газових родовищ, родовищ мінеральної та прісної води, піщано-гравійних сумішей, об'єкти промисловості та с/г підприємства. На території району $\epsilon$ 
45 тис. га земель обмеженого використання: охоронні зони водозаборів, трубопроводів, санітарні зони курорту Моршин. На територій Стрийського сміттєзвалища, площа якого становить майже 10 га, на даний час накопичено понад 750 тис. т відходів.

В свою чергу рекреаційна діяльність теж нерідко спричиняє негативний вплив на навколишнє природне середовище. Загрозою для довкілля є неконтрольоване будівництво рекреаційних комплексів та інфраструктури, вплив рекреантів, що полягає у витоптуванні, збідненні видового і кількісного складу біоценозу, пошкодженні деревостану, ущільненні грунту, випалюванні та засміченні території тощо. Для зменшення негативного впливу рекреантів необхідним $є$ організація території для рекреації та дотримання норм рекреаційної місткості.

\section{Висновки}

Територія Стрийського району володіє значними природними та історико-культурними рекреаційними ресурсами, а відтак - високим ресурсним потенціалом, який на сьогодні використовується досить неефективно. Подальший розвиток рекреаційної сфери залежатиме від раціонального використання рекреаційних ресурсів, насамперед природних, їх охорони від забруднення та виснаження. Пріоритетним також $\epsilon$ впровадження та популяризація нових видів рекреації, наприклад сільського зеленого туризму, з використанням історико-етнографічних особливостей територіï.

\section{References}

Chabanchuk, V. Yu., \& Melniichuk, M. M. (2015). Vykorystannia poliskykh lisovykh landshaftiv Rivnenshchyny u rekreatsii ta turyzmi. Nauk. zapysky Ternopilskoho nats. pedahohichnoho u-tu imeni V. Hnatiuka. Seriia: heohrafiia. Ternopil: SMP "Taip", 2(39), 147-153. URL: http://nbuv.gov.ua/UJRN/ NZTNPUg_2015_2_24 (in Ukrainian).

Chyr, N. V., \& Hrab, O. M. (2015). Pryrodoresursnyi potentsial likuvalnykh hriazei dlia potreb sanatornokurortnoho hospodarstva Ukrainy. Materialy mizhnarodnoi naukovo-praktychnoi k-tsii "Suchasni osoblyvosti formuvannia i upravlinnia innovatsiinym potentsialom rehionalnoho rozvytku turyzmu ta rekreatsii iz zaluchenniam molodizhnoho resursu", 15-17 zhovtnia 2015 roku. T.: TNTU, 206-208 (in Ukrainian).

Horyn, I. (2018). Pryrodni turystychno-rekreatsiini resursy Lvivshchyny: struktura, otsinka potentsialu ta kharakteru suchasnoho vykorystannia. Nauk. zapysky Ternopilskoho nats. pedahohichnoho u-tu imeni V. Hnatiuka. Seriia: Heohrafiia, 2, 137-146. URL: http://nbuv.gov.ua/UJRN/NZTNPUg_2018_2_18 (in Ukrainian).

Kalyn, B. M., \& Butsiak, A. A. (2017). Ekolohichna otsinka ta potentsial turystychno-rekreatsiinykh resursiv Brodivskoho raionu. Naukovyi visnyk LNU veterynarnoi medytsyny ta biotekhnolohii. Seriia: Silskohospodarski nauky, 19(74), 15-19. doi: 10.15421/nvlvet7404 (in Ukrainian).

Mahas, M. Ia. (2003). Morshynske rodovyshche mineralnykh rozsoliv - peredumova funktsionuvannia kurortu Morshyn. Nauk. visnyk Natsionalnoho tekhnichnoho universytetu nafty i hazu. Iv.-Frankivsk, 2(6), 93-96 (in Ukrainian).

Nazaruk, M. M. (2018). Lvivska oblast: pryrodni umovy ta resursy. Lviv: Vydavnytstvo Staroho Lev (in Ukrainian).

Pankiv, N. Ye. (2019). Pryrodookhoronni terytorii yak baza rozvytku ekolohichnoho turyzmu u Lvivskii oblasti na prykladi natsionalnoho pryrodnoho parku "Skolivski Beskydy". Nauk. visnyk NLTU Ukrainy, 29(5), 88-92. doi: 10.15421/40290517 (in Ukrainian).

Perkhach, O., \& Hamoniak, M. (2016). Ekolohoheohrafichne vyvchennia poverkhnevykh vod administratyvnoho raionu yak napriam naukovykh doslidzhen studentiv. Problemy bezperervnoi heohrafichnoi osvity i kartohrafii, 24, 84-87. URL: http://nbuv.gov.ua/UJRN/Pbgo_2016_24_20 (in Ukrainian).

Prohrama rozvytku turyzmu v Stryiskomu raioni na 2017 r. URL: http://stryirairada.gov.ua/rishennja/224-1.pdf (in Ukrainian).

Tretiak, A., \& Hrebennyk, H. (2014). Pryrodni rekreatsiini resursy Ukrainy: stan vykorystannia ta potentsial. Zemlevporiadnyi visnyk, 8, 41-45. URL: http://nbuv.gov.ua/UJRN/Zv_2014_8_11 (in Ukrainian).

Vyshnevskyi, V. I., \& Kosovets, O. O. (2003). Hidrolohichni kharakterystyky richok Ukrainy. K.: Nika-Tsentr (in Ukrainian). 